\title{
POWER-KNOWLEDGE RELATIONS OF THE ELDER AND THE YOUNGER MADURESE MUSLIM SCHOLARS IN PROPAGATING ISLAMISM IN MADURA: A COUNTER-NARRATIVE
}

\author{
Abd A'la \\ Sunan Ampel State Islamic University Surabaya, Indonesia \\ E-mail: abdalabs@yahoo.com \\ Ahwan Mukarrom \\ Sunan Ampel State Islamic University Surabaya, Indonesia \\ E-mail: ahwanmukarrom1952@gmail.com
}

\begin{abstract}
This article examines the relationship between religion-politics and knowledge developed by the Kiai Tua and Kiai Muda in Madura. The Aliansi Ulama Madura (AUMA), or The Alliance of Madurese Ulema representing the Kiai Tua, and the Forum Kiai Muda (FKM) or The Forum of Young Ulema for Kiai Muda have actively propagated the idea of Islamism in Madura. By employing Foucault's theory of power relations, this article discovered that the relation of power and knowledge might put Madura at risk. This theory, which was constructed by the AUMA, FKM, and their organizational networks, may likely cause intolerant and exclusive views. Their religious understanding and publicity have a militant and robust desire to make their ideological narratives, mainly of Islamic revival, along with the aspiration to establish a global Islamic leadership system, come into existence. This resistant attitude subsequently makes the ideology grow into an extreme, radical, and intolerant movement. For this reason, several moderate groups, such as Pengurus Cabang Nahdlatul Ulama (PCNU) Pamekasan and associated autonomous bodies, have actively voiced peaceful religious narratives. These moderate narratives act as a counterbalance against the intolerant and exclusive religious ideas proclaimed by two aforementioned Islamist groups.
\end{abstract}

Keywords: Power relationship; the Kiai Tua; the Kiai Muda. 


\section{Introduction}

This article is the continuation of our previous works entitled "Kontribusi Aliansi Ulama Madura (AUMA) dalam Merespons Isu Keislaman dan Keumatan di Pamekasan Madura" and "Islam dan Agamaisasi Politik: Studi Analisis Terhadap Peran dan Pergerakan Forum Kiai Muda (FKM) Pamekasan Madura". 'These two previous research analyzed the two mentioned organizations' role-the Madurese Muslim Scholars Alliance (AUMA) and Younger Muslim Scholars Forum (FKM) - in leading the recent Islamism and the umma concept in Madura.

The contribution and the role of AUMA are significant because they keep actively voicing their aspirations through local, regional, and national channels. Moreover, FKM — established by AUMA - is also significant because it is meant to regenerate the youth religiosity to continue the elders' ideology and become the frontlines at the grassroots level, including mass mobilization. Not only on Islamic issues, but they had also been involved in the past presidential election as they supported the number-two candidates, Prabowo Subianto and Sandiaga Uno ${ }^{3}$. In 2014, they also agreed to make Prabowo Subianto-Hatta Rajasa as their political choice based on their consensus.

Apart from the AUMA's support for Prabowo-Hatta represented by $\mathrm{KH}$ Ali Karrar Shinhaji, several ulama from Madurese pesantren (Islamic boarding schools, abbr. PP) also had the same political aspirations such as: KH Abd Muqsith Idris (PP AnNuqayyah Guluk-Guluk, Sumenep), KH Taufiqurrahman (PP Mathlabul Ulum Jambu, Sumenep), KH Moh Syamsul Arifin (PP Darul Ulum Banyuanyar, Pamekasan), KH Djazuli Jauhari (PP Tengginah Proppo, Pamekasan), KH Syafiuddin Wahid (PP Darul Ulum Gersempal, Sampang), KH Abd Muhaimin Bari (PP Darut

\footnotetext{
1 Abd A’la, Ahwan Mukarrom, Mukhammad Zamzami, "Kontribusi Aliansi Ulama Madura (AUMA) dalam Merespons Isu Keislaman dan Keumatan di Pamekasan Madura”, Religió: Jurnal Studi Agama-agama, Vol. 8, No. 2 (2018).

2 Abd A'la, Ahwan Mukarrom, Mukhammad Zamzami, "Islam dan Agamaisasi Politik: Studi Analisis Terhadap Peran dan Pergerakan Forum Kiai Muda (FKM) Pamekasan Madura", Jurnal Review Politik, Vol. 8, No. 1 (2018).

3 "Ribuan Warga Pamekasan Madura Deklarasi Kemenangan Prabowo-Sandi, Masih Kukuh Sebut Menang 62 Persen", in suryamalang.tribunnews.com/2019/05/12/ accessed on Januari 3, 2020; "Kiai Madura Sebut Tak Main-main Mendukung Prabowo-Sandi” dalam jurnalmojo.com/2019/01/20/.
} 
Tauhid Injellan, Sampang), KH Nuruddin A Rahman (PP al-Hikam Burneh, Bangkalan), and KH Abdullah Khon (PP Raudlotul Muta'allimin I Sebeneh, Bangkalan). ${ }^{4}$

Furthermore, the double role of the kiai in Madura has been recognized by existing researches. Chalik (2010) stated that the kiais in Madura have two functions; as religious leaders (concerning spiritual aspects), and the leaders of the surrounding society (concerning the social-political aspects). Thus, they tend to combine religion and politics. ${ }^{5}$

They are progressing not merely in Madura, but also at the national level. They show their existence and spread their influence nationally. We can see how they supported the demonstration to defend Islam that happened three times periodically concerning the issue of "religious blasphemy" conducted by Basuki Tjahaja Purnama. AUMA, represented by KH Ali Karrar, also did the mediation with the ex-religious minister Lukman Hakim Saifuddin in the religious ministry building, Lapangan Banteng Jakarta, to clarify the issue of LGBT and the Islamic education books, which they considered having many mistakes on editing. ${ }^{6}$

These ulama contributions in Muslim issues, politics, and the concept of umma in Madura are interesting to study because of the following factor: the schema of the rooted patron-client relationship among Madurese tradition where the ulama have the strategic position and higher social status among the Madurese people. The ruling patrons who are rich, charismatic, religiously pious, and have a huge pesantren are positively considered to affect the surrounding society.

4 "Didukung Kiai se-Madura Prabowo Yakin Menang Pilpres" in www.liputan6.com/indonesia-baru/read/ 2068108/Accessed on June 29, 2017.

5 Abdul Chalik, "Religion and Local Politics: Exploring the Subcultures and the Political Participation of East Java NU Elites in the Post-New Order Era", Journal of Indonesian Islam, Vol. 4, No. 1 (2010).

6 Some of the attendees are KH Ahmad Muhammad Tijani (MUI) Sumenep, KH Fadloli M Rumam (AUMA) Pamekasan, KH Nurun Tajalla (Auma) Sampang, KH Syafiuddin Hasibin (AUMA) Pamekasan, KH Abd Ghoffar (NU) Pamekasan, KH Mahrus Abd Malik (Bassra) Sampang, KH Ja'far Shodiq (NU) Sampang, KH Jaiz Badri (Autada) Probolinggo, KH Lutfi Bashori (NU) Malang, KH Imam Ramli (NU) Jember, KH Imam Mawardi (Majlis Muwasholah) Sampang, KH Umar Hamdan (Forum Kiai Muda) Pamekasan, KH Fauzi Rosul (Bassra) Sumenep, KH Jurjis Muzammil (AUMA) Sumenep, and KH Ma'shum Tirmidzi. See "Ulama Madura Tabayun ke Menag Soal LGBT", in republika.co.id/berita/duniaislam/islam-nusantara/18/01/11/Accessed July 20, 2019. 
The rich patrons would provide jobs, security, and infrastructure. Meanwhile, the charismatic ulama or kiais would give religious understanding and teach the umma (keumatan) concept with the guaranteed religious merit as obeying their commands.

Besides the two mentioned articles above, the writings on the relation of kiai, santri (student), and the common people are well explained in the following works of Iik Arifin Mansurnoor, ${ }^{7}$ Ali Maschan Moesa, ${ }^{8}$ Abdul Chalik, ${ }^{9}$ Yanwar Pribadi, ${ }^{10}$ and Abdul Gaffar Karim. ${ }^{11}$

The difference between this article and the previous articles that we wrote lies in the object of study. If the previous articles revealed the context in which those organizations are building Islamism, this article analyzes how the two organizations design the relation of

\footnotetext{
7 As religious leaders, the ulama contributed to creating a network of significant followers and colleagues that work together on the stability facing Madura's social and political change. See Iik Arifin Mansurnoor, Islam in an Indonesian World: Ulama of Madura (Yogyakarta: Gadjah Mada University Press, 1990).

${ }^{8}$ In the book Kyai dan Politik dalam Wacana Civil Society, Moesa analyzes the dynamic of ulama in Madura through Badan Silaturahmi Ulama Pesantren Madura (Bassra) in developing the discourse of civil society. Applying Herber Blumer's symbolic interactionism, Moesa explained the contribution of the kiai in constructing society toward a more civilized life. See Ali Maschan Moesa, Kyai dan Politik dalam Wacana Civil Society (Surabaya: Lepkiss, 1999).

9 This article emphasizes that the kiais of NU are considered by their followers as having two functions, the leaders in spiritual and social political aspects. The kiais in Madura tend to combine the religion with politics. Chalik, "Religion and Local Politics".

10 Yanwar examined three important elements of the santri traditions among the Madurese people, which are pesantren (representing traditional Islam's education), Nahdlatul Ulama (representing Islamic organization), and kiai (representing Islamic scholarly figure). The three elements are interdependent in building a complex relation between Islam and politics as practiced by the Madurese. According to Yanwar, the Madurese are still preserving sacred values of religion, as seen in the strong influence of the pesantren, Nahdlatul Ulama, and kiai on worldly and religious matters. Madurese believe that Islamic sharia is very important and has to be applied in the whole aspects of everyday life. Yanwar Pribadi, "Religious Networks in Madura: Pesantren, Nahdlatul Ulama, and Kiai as the Core of Santri Culture", alJami ab: Journal of Islamic Studies, Vol. 51, No. 1 (2013).

${ }^{11}$ Gaffar argued that kiai and pesantren play central role in the provincial election of 2000-2005 in Sumenep. However, Gaffar admitted that despite the control of pesantren on political recruitment processes, these institutions might not have a clear purpose in running their political power. See Abdul Gaffar Karim, "'Pesantren' in Power: Religious Institutions and Political Recruitment in Sumenep, Madura", RIMA: Review of Indonesian and Malaysian Affairs, Vol. 42, No. 1 (2008).
} 
power and religious-political knowledge between the AUMA-FKM and the society as well as the santri. In this respect, this study also reveals these organizations' networks, especially in propagating political Islam's perspectives and the concept of umma in Madura.

This article employs the power relation theory by Michel Foucault. As Foucault argued, power is a productive entity that always searches for networks and relations in everyday life, places, and social systems. That is why Foucault emphasized that power is not located on an element or a structure, rather always moves in the totality of a system in the form of networks or social relations, ${ }^{12}$ encompassing the fields of economy, education, culture, politics, knowledge, and even in a spiritual aspect of religion.

\section{AUMA and FKM: Historical Sketch, Ideology, and Networks}

There are causing factors behind the birth of the AUMA, which are mainly responses toward crucial issues on Islamism at the local and national levels. Generally, the factors can be divided into external and internal. The birth of the AUMA was externally driven by happening issues around Islam in Indonesia at that time. One of the main issues behind its birth was the burning of a Mosque in Tolikara, Papua. When the news occurred, a group of Madurese Muslim scholars was worried about the conflict since many of the Muslims in that region come from Madura, especially from Sampang and Bangkalan.

To pray for the conflict's goodness, they held a religious ritual such as istigäthah (mass prayer) for all Muslims in Tolikara, while hoping that the government would do justice to the conflict. ${ }^{13}$ Many ulama and religious figures from the different organizational backgrounds (i.e., NU, Muhammadiyah, Sarekat Islam, al-Irsyad) gathered in the held ritual. Since then, an initiative occurred to establish a legal organization or association to advocate for the Muslim society. This association was later named AUMA. Then, a prominent intellectual actor behind the ulama gathering across the different organizational background, KH. Ali Karrar, was appointed to be the leader of the AUMA. KH. Toha Amin, the leader of AUMA Pamekasan, narrated:

12 Ibid., 123. 
"The AUMA was created at the exact time when the Tolikara incident happened there. So, Kiai Karrar, as the ulama in Pamekasan, initiated the mass prayer. The istighathah and prayers were chanted to God and asked Him to help the government to do justice in that case. In the gathering, he invited all the religious figures from across the diverse organizations like NU, Muhammadiyah, Serikat Islam, Front Pembela Islam. Since then, they felt a need to have a kind of association and decided to create this association named Madurese Muslim Scholars Alliance (AUMA). So, the birth of the AUMA is based on the people's aspiration especially the ulama in Pamekasan in responding to the government action to the conflict." ${ }^{, 14}$

Besides the mentioned external factor, the birth of the AUMA was also driven by the vacuum of ulama or kiais association in Madura. The existing association was a Madurese pesantren organization named BASSRA. ${ }^{15}$ Based on our observation, some of the ulama who were the members of the BASSRA are decided to resign from the organization because the organization is considered no longer able to respond to the happening issues in Madura, and its movement is becoming less significant. In this situation, Kiai Karrar, initiated to build a new organization to accommodate the aspiration from the resigned members of BASSRA and gather new members.

Finally, in October 2015, AUMA $^{16}$ was officially declared in PP. Nurul Kholil, Bangkalan, Madura, who was led by KH. Zubair

$14 \mathrm{KH}$. Nawawi Toha (the leader of AUMA Pamekasan), Interview, Pamekasan, August 6, 2018.

15 For a more comprehensive understanding of this group, see Abd A'la, Mukhammad Zamzami, Nur Hidayat Wakhid Udin, Ahmad Fathan Aniq, "Islamism in Madura: From Religious Symbolism to Authoritarianism", Journal of Indonesian Islam, Vol. 12, No. 2 (2018), 164-167.

16 The organizational structure of AUMA generally consists of Central Committee, Regional Committee, and District Committee. The office of the central committee is located in Jl. Raya Proppo, Desa Lenteng, Kecamatan Proppo, Kabupaten Pamekasan. The exact location is in PP. Ma'had Islami Salafi Darut Tauhid (MISDAT) on the waqf land of Alm. H. Muhammad Asy'ari Dauri financed by KH. Zubair Muntashor, for Islamic dakwah and the development of Islamic knowledge. Meanwhile, the Regional Committee Office is located in PP. Mutaallimin II, under the leadership of KH. Abdullah Khon Thobroni, Sebeneh, Bangkalan; Sampang Regional Committee Office is located in PP. Nurul Iman, KH. Ahmad Yahaya Syamsul Arifin, Sogiyen Omben, Sampang; Pamekasan Regional Committee Office is located in PP. Asy-Syaidul Kabir, led by KH. Mundzir Kholil, Sumber Batu Blumbungan, Pamekasan; Sumenep Regional Committee Office, is located in PP. 
Muntashor. To the present day, this organization has become the gathering place for the local ulama/kiai in Madura. However, the birth of AUMA was earlier than that. Based on our field data, the central leaders declared the gathering on July 21, 2015, located in PP. Darul Ulum Banyuanyar, Pamekasan, Madura. It is interesting to see that despite the official declaration in Bangkalan, the headquarter of AUMA is located in Lenteng village, Kecamatan Proppo, Pamekasan.

Furthermore, the Younger Madurese Muslim Scholars Forum (FKM)'s birth was purely initiated by "the elders" who want to expand the movement among the elder kiai and the younger generation to execute the aspiration and the ideology in the grassroots. Therefore, FKM was created to lead the society-santri mass.

FKM is born out of AUMA. While AUMA's members are the leaders of pesantrens, the members of FKM are the lora/gus. Lora or gus (also: bhindhârâh) refers to the family members of kiai who have pesantren. The title is a form of respect to the sons and daughters of the kiyayi's family. ${ }^{17}$ According to Zamakhsyari Dhofier, lora is the one who can possess the skill of the kiai, both his knowledge and his spiritual capacity. ${ }^{18}$

FKM was thus initiated by the kiai members of the AUMA. This organization was established on August 9, 2015. In its structure, the members are the lora and ustaz aged from 20 to 40 years old. ${ }^{19}$ The organization centerd on Pamekasan is led by lora Umar Hamdan Karrar bin KH. Ali Karrar Shinhaji and his secretary lora Imadul Haq Fadholi bin KH. Fadholi Moh. Ruham. This structure is almost similar to that of AUMA. The fathers would participate in the AUMA, while the sons participate in the FKM.

al-'Isaf, under the leadership of KH. Jurjis Muzammil, Klaban Guluk-Guluk, Sumenep.

17 To call a son/family of the kiai, each region has a respect title for them. Gus is used among Javanese. Lora is a unique title only used among Madurese. Meanwhile, bhindhârâh is a title used among the kiai Pendalungan/ Southern and Eastern East Java. See Abdul Chalik, "Elite Lokal Berbasis Pesantren dalam Kontestasi Pemilihan Kepala Daerah di Jawa Timur", KARSA: Jurnal Sosial dan Budaya Keislaman, Vol. 23 No. 2 (December 2015), 371. Nurcholish Madjid, Bilik-bilik Pesantren: Sebuah Potret Perjalanan (Jakarta: Paramadina, 1997), 24.

18 Zamakhsari Dhofier, Tradisi Pesantren: Studi tentang Pandangan Hidup Kyai (Jakarta: LP3ES, 1982), 32.

19 Anggaran Dasar Forum Kiyai Muda Madura, published by FKM Madura. 
The mission of AUMA and FKM is highly nuanced in Islamic missionary endeavor as expressed in their spirit to struggle, purify against all forms of religious deviations among the Madurese.

There are four main targeted work of the AUMA and FKM that are; to wage war against Shiite, Wahhabi, liberal, and blasphemous actors and ideologies. They call these elements as SYIBILIP. For them, these elements are not only wrong but also deviated from the true Islamic teachings. Thus, they do not compromise these elements and ready to eradicate them from the religious life. According to them, the deviation of SYIBILIP is not only negatively affecting religious life but also creating social disintegration in people's life and further disintegrate the national ideology of NKRI. ${ }^{20}$

Their counter-narrative against SYIBILIP is based on the normative ideology and doctrine of amr ma'rüf naby munkar. Their ideology is thus generally affirming that of the Islamic Defender Front (FPI). Practically, a close relationship can be seen between the members of AUMA-FKM and the members of FPI. The compromise by AUMA-FKM with the thoughts and action of FPI is not without reason, as many of the members are affiliated to the Islamic Defender Front, such as KH Jurjis Muzzammil (the leader of PP al-Is'af Gulukguluk/the leader of FPI Sumenep), KH Moh Ali Salim Syaifuddin (the leader of PP al-Islah/the leader of FPI Pamekasan), KH Nursaif Syaiful Jabbar (the leader of Ponpes Darut Tauhid/the leader of FPI Sampang), and KH Saiful Qohhar Thobroni (the leader of Ponpes Raudlatul Muta'allimin Al-Aziziyah/the leader of FPI Bangkalan).

AUMA and FKM are not only building a network with the FPI. The kiais, together with FPI, also made friendship with the Partai Keadilan Sejahtera (PKS), as seen when KH Saiful Qohhar Thobroni openly supported PKS and Prabowo-Sandi in the 2019 presidential election. Moreover, there are numerous cadres of FPI who participate as legislative candidates of PKS such as Habib Muhammad, SE, and Ustadz Akhmad, S.Sos. ${ }^{21}$

In general, the networks of AUMA-FKM share a similar ideology. AUMA-FKM had also involved in the demonstration to defend Islam "Bela Islam 212" together with the groups of political

\footnotetext{
${ }^{20}$ KH Ali Karrar Shinhaji (Ketua AUMA), Interview, Pamekasan June 22, 2017.

21 "PKS dan FPI Siap Menangkan Prabowo-Sandi di Madura" in news.okezone.com/read/2019/02/27/ 605/2023531/Accessed January 20, 2020.
} 
Islam, including the Wahhabi followers. Despite the spirit of antiSYIBILIB, AUMA and FKM have a close relationship with the Wahabi groups. One of the reasons is because the anti-SYIBILIP campaign is key to get the society-santri mass support among the Nahdliyyin.

\section{Criticizing Shia and the Spirit of "Islam Nusantara" by NU, While Tolerating Wahhabism}

According to the perspective of AUMA and FKM, ideologies outside their version of Abl al-Sunnab wa al-Jamā'ah, especially Shiite doctrines, Wahhabism, liberalism, and religious blasphemy (SYIBILIP), must be rejected. Thus, their mission is to maintain, defend, and strengthen the teachings of Abl al-Sunnah wa al-Jamäah.

Regarding the Shiite existence in Madura, we found an interesting fact that AUMA-FKM is totally against the Shiite group. They assumed that Shia Islam has a dangerous ideology. In the following sentences, we found out two reasons why they resist Shia doctrines.

First, according to AUMA-FKM, Shia is not only religiously deviant, they also have different teachings from Sunni Islam as the majority doctrines embraced by Indonesian Islamic organizations. One Shia doctrine that they reject is tabirif al-Qur'ān which says that the existing Qur'an is a faked holy book and has undergone many changes and reductions from its originality.

Second, they refer to the released fatwa by MUI of East Java Province that Shia's legal status is deviant and misleading, as documented in the fatwo of Majlis Ulama Indonesia (MUI) of East Java Province no. kep-01/SKF-MUI/JTM/1/2012. ${ }^{22}$ Therefore, their teachings cannot legally be introduced and spread to the public. Meanwhile, AUMA-FKM sees that the central MUI has not decided on Shia deviance's legal binding. In this case, AUMA-FKM is committed to advocate and struggle for the release of the fatw $\bar{a}$ regarding the Shia deviance by the central MUI. Thus, by having legal organization status, AUMA-FKM has the access and legal power to

22 The released fatwa by Indonesian Ulama Council (MUI) East Java Province number: Kep-01/SKF-MUI/JTM/I/2012 contains the decision from regional MUIs stating that the Shia teachings (especially Imamiyah/Itsna Asyariyah or the ones that take name of mazhab Ablul Bait and alike) as well as the teachings similar to Syiah Imamiyah/Itsna Asyariyah are deviant and misleading. See the fatwa of MUI East Java Province No. Kep-01/SKF-MUI/JTM/I/2012. 
control and reject the Shia existence in Indonesia, especially among the Madurese. An informant said:

“... Constitutionally, we are struggling to make the central MUI fatwa regarding the Shia deviance released. East Java (MUI) already released the fatwa $\bar{a}$. Now, we're forcing central MUI to release that. I met MUI several months ago....,23

Besides their resistance to the Shia in Madura, they also reject the spirit of Islam Nusantara (Archipelagic Islam) echoed by NU. They insisted that Islam should be Islam without any modification. They are against labeling Islam with any other elements such as Islam Nusantara, Islam Arab, and so forth. They accused that the labeling of Islam Nusantara is a form of methodological deviance to the teaching of the al-salaf al-sälih (the pious forefathers).

This labeling, they argued, is misleading and has to be rejected. Then, it is undoubtful that such an attitude of AUMA and FKM leads them to become the critic of the popularized terms. KH. Umar Hamdan Karrar, as the leader of FKM, said:

“... FKM totally disagrees with such modern ideas which are deviating from (keaswajaan) the pious forefather's teachings and their methodologies. Meaning that such ideas of Islam Nusantara and other things can be called deviant from the method developed by al-salaf al-salib. We wage war against that." ${ }^{24}$

Furthermore, FKM secretary-general, Imadul Haq Fadholi stated that his group does not accept the spirit of religious moderation preached by Muslim scholars of Nahdliyyin like Habib Muhammad Luthfi bin Yahya, KH A. Mustofa Bisri, Habib M. Quraish Shihab, and other moderate figures. Imadul Haq-who also called himself as a young Nahdliyyin — said that "the more moderate those figures, the more we don't like them". ${ }^{25}$ This resistance contradicts the common acceptance by the majority Nahdliyyin toward those figures. It also contradicts the religious moderation carried out by NU as its organizational foundation and practice in everyday life as an aspect of civilization. Nahdliyyin usually builds harmony with the surrounding environment as the universal aspect of Islam requires them to accommodate existing particular cultures in

\footnotetext{
${ }^{23}$ KH. Ali Karrar Shinhaji (the leader of AUMA), Interview, Pamekasan June 22, 2017.

${ }^{24}$ KH. Umar Hamdan Karrar (Ketua FKM), Interview, Pamekasan, July 30, 2018.

${ }^{25}$ KH. Imadul Haq Fadholi (Secretary General of FKM), Interview, Pamekasan July 14, 2017.
} 
which they live. This approach is meant that the presence of Islam can create hospitality in the surroundings. This model is adopted from the cultural approach practiced by the earliest muballigh (wali) of Islam. It is commonly known that the muballigh did not employ exclusive Islamic symbols (i.e., Arabic styles) and adopted the local ones. They integrated Islamic teaching with the localities so that Islam can cope with Indonesian cultures.

The resistance toward the spirit of Islam Nusantara ala NU seems to contradict the AUMA-FKM's behavior toward Wahhabism, although they resisted the doctrine in their organizational credo. They see Wahhabism as deviant and the enemy of Islam that must be countered and eradicated in Madurese and generally Indonesian Islamic landscape. According to them, one of their behavior that must be resisted is the exclusive truth claim and labeling different "others" as infidel as seen in how they justify certain rituals commonly held among Madurese from NU and SI traditions as shirk (idolatry) and bid'ah (heresy).

Nevertheless, the anti-Wahhabism doctrine seems to contradict their practical behavior. The AUMA and FKM in Pamekasan and other regions, in some ways, are accepting the thoughts propagated by Wahhabis. In other words, their resistance to the Wahhabi doctrine is not as radical as their rejection of the Shiite ideology. As we found out that the attitude of AUMA-FKM tends to tolerate and sympathize with the religious activities conducted by groups of Wahhabis-as long as the activities are conducted in their territories and not exposed to the public. Today, a local said, the center of Wahhabi religious activities is permitted only in Ridwan Mosque, Pamekasan District, while there is a possibility that their activities can be extending since there is not any obvious space restriction. The recent development of the AUMA-FKM's permissive attitude toward the Wahhabism creates different responses from pros and cons among the diverse Islamic organization in Pamekasan.

Some of them question the commitment of AUMA-FKM in eradicating the spread of Wahhabism in Pamekasan. According to Ahnu Idris, the leader of santri movement called Gerakan Santri dan Palajar Rabmatan Lil 'Alamin (GESPER), when resisting the upcoming preaching of a Wahhabi figure, Ust. Basalamah, which was planned to give a religious lecture in one of the mosques in Pamekasan, AUMA- 
FKM did not take any action. ${ }^{26}$ Responding to that, KH. Ali Karrar Shinhaji, the leader of the AUMA clarified that their permissiveness to the event was not toleration since Wahhabism and Shia in their doctrines and practices are well deviant and thus became their enemies. The "permissiveness" was rather because of uncertainty on its legal clarity. ${ }^{27}$

He further underlined that the FKM — as the extended body of AUMA — did not have a legal binding to act upon Wahhabism. Moreover, he said that so far, there was not any legal clarity on the deviance of Wahhabism. Then, this unclarity was what made them permissive to the followers of Wahhabism in Pamekasan, yet FKM struggled to impose the deviant status of the Wahhabism to put into an act of religious deviance. Only with this normative base, they would be able to respond and act upon the Wahhabism and all their activities held in Pamekasan. ${ }^{28}$

In this case, we argue that AUMA and FKM tend to take side with the Wahhabism in its purification and intolerant behavior but not in its religious practice (amaliyab). In some cases, they affirm the al-Bayyinat group's ideas regarding Shia's deviance and the toleration toward Wahhabism. They consider Habib Zein al-Kaff-the head of the group-as one of the NU representatives. However, there is an ambiguity in the statement of Habib Zein that once claimed: "Wahhabism remains in the category of Abl al-Sunnah, but not with Shia". ${ }^{29}$ He stated it as if he agreed that the doctrine of takfiri (labeling another school of thought as infidel) used by Wahhabi is permissible. On the other hand, NU does not employ the doctrine of takfiri.

26 Ahnu Idris (the leader of Ormas Gerakan Santri dan Pelajar Rahmatan Lil'alamin (GESPER), Interview, Pamekasan August 17, 2016.

27 Based on the interview notes with KH. Ali Karrar Shinhaji, Pamekasan June 22, 2017.

28 Ibid.

29 "Habib Zein Al-Kaff: Kalau Wahabi Masih Ahlussunnah, Sedangkan Syiah Bukan" in nahimunkar.org/Accessed in June 26, 2017. Habib Zein al-Kaff is well known among sympathizers of anti-Shia movement. As the head of Al-Bayyinat, Habib Zein Al-Kaff often gives lectures on Shia ideology. In the official website of al-Bayyinat Indonesia, it is written that the establishment of the foundation is to counter the Shia movement. This Islamic movement, we see, is far from the culture of Nahdliyyin, who does not usually label others as infidels. The ideological model proposed by Habib Zein is closer to the Wahhabism rather than NU in its cultural manifestation. 
In fact, Habib Zein, Kiai Karrar, and $\mathrm{KH}$ Abdusshomad Buchori (the head of MUI of East Java) are the men behind the release of the fatwo regarding the deviance of the Shia mazhab (school of thought). The Shia deviance, they insisted, is in the category of usiul (foundational) in Islam. The fatwo stated that the Shia ideology would make trouble in the society when its missionary is permitted and will create horizontal conflict. ${ }^{30}$

Besides Shia and Wahhabism's main resistance, AUMA-FKM is also partnered with the Islamic Defender Front (FPI) who is also against Shia. They are always in partnership with FPI in expressing their thoughts and movement, such as in the ideology of amr ma'ruif naby munkar and their political choice. In the 2014 and 2019 presidential election, their political legacy goes to Prabowo. ${ }^{31}$ Based on their intimacy, we argue that AUMA and FKM are "NU in ritual and FPI in their movement orientation". Besides, the influence of the FPI is quite significant in Madura as seen in the mobilization of FPIaffiliated kiai/lora in the 2019 presidential election that succeeded to gain 62 percent voters for Prabowo-Sandiaga.

\section{Power Relation of Knowledge and Politics among the Elder and the Younger Kiais}

As the elders, AUMA actively contributes to producing religious thoughts and ideas supported by the younger kiais FKM. They claim to be a religious organization, meaning that the operation of these bodies is purposively religious. Yet on a practical level, their claims cannot be justified. As we observed, their religious movement of anti-SYIBILIP is somehow enacted within political issues. Then, we see that these organizations are not merely religious-purposed association since we cannot ignore their political participation and interest.

Many evidence shows the political role and participation of the AUMA-FKM members at the regional and national levels. For example, they participate in practical politics in Jakarta where Kiai Karrar attended the Ijtimak. Ulama Jakarta (Muslim scholars gathering in Jakarta) in the 2019 presidential election contestation. He was also

\footnotetext{
30 See the fatwa of MUI East Java Province no. Kep-01/SKF-MUI/JTM/I/2012.

31 "Ribuan Warga Pamekasan Madura Deklarasi Kemenangan Prabowo-Sandi, Masih Kukuh Sebut Menang 62 Persen" in suryamalang.tribunnews.com/2019 /05/12/Accessed on July 20, 2019.
} 
involved in the GNPF MUI (National Movement on Defending Fatwa of Indonesian Ulama Council) as an attempt to get rid of Ahok (a strong Chinese candidate) from winning the Jakarta governor's election in 2014.

On the other hand, AUMA and FKM are also trying to strengthen their position by approaching and stepping into the local government structure of legislative, judicative, and mainly executive bodies. This approach strengthens their legal-formal position and somehow subduces the structural hegemony built by the legal-formal basis. In other words, they intend to be benefited from using and having a structure of institution that is legitimated and has legal protection. We can see how KH. Ali Karrar Sinhaji visited the regional police in East Java on Wednesday (05/12/2018), ${ }^{32}$ to maintain a good relationship between ulama and the police officers. In this case, the synergy is a keep-in-touch strategy by AUMA to partner with the police department of East Java.

The political image of the AUMA-FKM has not only been exposed to the 2019 presidential election but has long been started in 2014 when Kiai Ali Karrar and his Madurese Muslim Scholars Alliance supported Prabowo Subianto-Hatta Rajasa. Together with the alliance, he showed up as the kiai representative who resisted the general election result in the constitutional court and demanded justice and fairness. ${ }^{33}$ His political image in 2014-2019 had been intensely exposed through his organization AUMA together with $\mathrm{KH}$ Umar Hamdan of FKM. As highlighted in a national newspaper, together with $\mathrm{KH}$ Abd Muqsit Idris (PP Annuqoyah Guluk-guluk Sumenep), KH Taufiqurrahman (PP Matlabul Ulum, Sumenep), KH Moh Syamsul Arifin (PP Durul Ulum, Banyuanyar, Pamekasan, KH Djazuli Jauhari (PP Tengghina Proppo, Pamekasan), KH Syafiuddin Wahid (PP Gersempal Sampang), KH. Abd. Muhaimin Bari (PP Enjellen, Sampang), KH Nuruddin A Rahman (PP Al Hikam, Bangkalan), and KH Abdullah Khon (PP Raudlatul Muta'allimin,

32 "Kapolda Jatim Sambut Kunjungan Ketua Aliansi Ulama Madura" in https://tribratanewspoldajatim.com/berita/MTA2NTc=/Accessed on May 20, 2019.

33 "Aktivis Muda NU Sayangkan Sikap Politik Kiai Madura" dalam santrinews.com/Nasional/1532/Accessed on January 13, 2018. 
Bangkalan), Kiai Karrar declared his support for the candidate pairs Prabowo-Hatta. ${ }^{34}$

In the past 2019 presidential election, before Prabowo chose Sandiaga Uno as his vice candidate, Kiai Karrar supported Ustadz Abdul Somad (UAS) as a vice-president candidate with Prabowo Subianto. They believed that UAS was able to make Indonesia better. ${ }^{35}$ Yet, their voices were eventually ignored and Prabowo selected Sandiaga Uno as his vice candidate. However, The Madurese Muslim Scholars Alliance decided to declare their support that was officially signed by kiai representatives from the four regencies in Madura. The declaration took place in Pamekasan. ${ }^{36}$

Kiai Karrar gave his speech in a forum held in di PP al-Ihsan Jrangoan Sampang as follows:

"The honorable mashayileh (teachers), habäib (the prophet's living descendants), ulama, kiai, dais, ustaz/ustazah (preachers), let us give enlightenment that people will realize to never again vote for a leader who harms the future of Islam, our grandsons, and all Indonesian. Let us participate in the istighathah for the victory of no. 2 (Prabowo-Sandi), let us solidify the ukbuwwah Islamiyah for the sake of our national flag, for the sake of Pancasila, for our nation Indonesia. We vote for Prabowo-Sandi". ${ }^{37}$

To further analyze these organizations' contributions in religious and political thoughts, we refer to Foucault's theory saying that power is productive and reproductive. This will infer two things:

First, reproduction means the ability to re-create and preserve. The reproduction of power carries an understanding that power has flexibility in defending, preserving, and re-strengthening its position and status. The production and reproduction of power happen in long and complex processes. The complexity can run in numerous sectors, both through normative legalities such as law constitutional law and traditional values includes religious, cultural, and customary beliefs. In this case, the reproduction of power by AUMA-FKM

34 "Kiai Pesantren di Madura Keluarkan Tausiah Dukung Prabowo-Hatta", in regional.kompas.com/read/2014/06/24/2010301/Accessed on January 27, 2017.

35 "Aliansi Ulama Madura Dukung Ustad Abdul Somad Jadi Wapres Prabowo" in suaraindonesia.co.id/read/1011/20180809/174828/Accessed January 20, 2019.

36 The kiais represented the four regencies were $\mathrm{KH}$ Abdullah Khon Th (Bangkalan), KH Faurok Alawi (Sampang), KH Ali Karrar Shinhaji (Pamekasan), and KH Jurjis Muzzammil (Sumenep).

37 An observation in PP. al-Ihsan Jrangoan, Omben, Sampang when Sandiaga Uno visited the place for asking support in the 2019 presidential election. 
refers to the real attempt to synergize the constitutional law and Islamic values (Islamic sharia) at the regional and national levels. In the Foucauldian perspective, the attempt to reduce the constitutional law into the sharia — as enacted by AUMA-FKM-is an instrument to produce and reproduce power while aimed to strengthen their bargaining position.

So does the reproduction strategy through the discourse of knowledge, the members of AUMA and FKM, who are also the leaders of pesantrens in Madura, are making the educational institutions to strengthen their influences and power among the grassroots. As explained before, this Madurese kiais produce Islamic discourse $A b l$ al-Sunnab wa al-Jamā'ah, while preventing the community and the society from the hereditary and deviant thoughts. This kind of knowledge reproduction - as thought by Foucault - is one of the ways to prolong and preserve the hegemony of the AUMA and FKM kiais as the religious leader for laypeople. This is in fact because of the ability of the power to disseminate its influence in all aspects of life and thus able to condition the society in the desired way.

Second, power is commonly considered a single entity and centered on one individual or a certain group. The fact is, Foucault argued, the power extends into the structures and systems. The power is present, and it penetrates all of the life aspects. It has a total character that can move from one location to another, making relations and networks. Its universality enables the power to discipline a body and condition a society. Concerning this, religious terms have many indications of the body's discipline such as obedience, loyalty, the hell-heaven promises that become the strong instrument to discipline and condition a society. This is what the AUMA and FKM try to produce images of SYIBILIP groups and the groups that are having different political commitment as "the other".

As argued by Horikoshi and Mansurnoor, the position of the kiai in central in upholding the religious-cum-political thoughts. Their charisma is a necessary capital to influence laypeople and santri's political orientation. The greater the charisma of a kiai, the greater power he gains, which means that the kiai's charisma is the indicator of how great is his influence on the people. In this way, he can 
intervene and even hegemonize voters in their political choice. In this case, the voters are relying on their "obedience to the kiai/guru. ${ }^{38}$

Their obedience to the kiai underlies their submission toward the spiritual competence and authority as expressed in the charisma of the kiai. Martin van Bruinessen described seven necessary capitals that build kiai' charisma: (1) the religious competence in the fields of figh (Islamic jurisprudence), tafsir (Quranic exegesis), Islamic history, and so forth, (2) the institutional engagement such as owning pesantren, involving in Islamic social organization, (3) the networks with other kiais and family kinship, (4) the relation to the center of power, (5) the personal quality which is shown in his charisma, his dashing appearance, and friendly personality, (6) the noble descendant of great kiais, and (7) well-established financial state. ${ }^{39}$ These strengths_-admittedly_-build his acceptance, honor, and recognition from the people and santri. While the relation with central powers, intra-kiai networking, and the nobility are the source of legitimation, his well-established family life amplifies his pride. Therefore, the kiais' position is always in the highest social status among the social elites.

By creating the image of SYIBILIP as "the other", dangerous, and threatening toward the Madurese, AUMA and FKM are, at least, attempt to grow their solidarity and authority among the followers. Then, this creation of an enemy image will produce a kind of identification of the in-group as right and "the other" as wrong. The higher the group's self-identification as the right, the higher its antipathy to the others. In reverse, the rooted creation of the enemy image by FKM and AUMA will be able to reduce the internal conflict in their groups because they face the same enemy outside their groups, which they consider much more dangerous to them. ${ }^{40}$

The networks of AUMA and FKM are extending to many structures and systems, from pesantren MISDAT, MISDAT, Islamic Defender Front FPI, Islamic Defender troops (LPI), 212 group, power relation of the kiais encompassing all elements of the pesantren community-santri, alumni, and the surrounding society. With

\footnotetext{
${ }^{38}$ Hiroko Horikoshi, Kyai dan Perubahan Sosial, Trans. Umar Basil and Andi Muwarly (Jakarta: P3M, 1987), 1-3. Mansurnoor, Islam in an Indonesian World, 19.

39 Martin van Bruinessen, NU: Tradisi, Relasi-relasi Kuasa, Pencarian Wacana Baru (Yogyakarta: LKiS, 1994), 152.

40 J.F. Dovidio, M. Hewstone, P. Glick, and V.M. Esses, "Prejudice, Stereotyping and Discrimination: Theoretical and Empirical Overview", in The Sage Handbook of Prejudice, Stereotyping and Discrimination (California: Sage Publication, 2010), 6.
} 
networking, AUMA and FKM have a great opportunity to create a powerful and well-rooted authority.

Furthermore, the fact that AUMA is managed by the elder kiais and FKM by the younger kiais makes the organizations the different bodies yet closely tied. There are two factors behind their emotional ties.

First, AUMA and FKM are led by two Muslim figures from one family, which is the big family of PP. Machad Islami Salafi Darut Tauhid (MISDAT) Ulumuddin. KH. Ali Karrar Shinhaji is the leader of AUMA, and his son KH. Umar Hamdan Karrar, is the leader of FKM. They are assisted by the general secretary of each organization, named KH. Fudholi Moh. Ruham (The head of PP al-Fudhola) and his son KH Imadul Haqq Fadholi. With such leadership patterns, AUMA and FKM are inevitably having very close relations in their cultures and structures. Besides, the previous organizational experiences of the leader in Sarekat Islam and the secretary-general of the AUMA in Nahdlatul Ulama make them capable of attracting greater mass.

Second, AUMA and FKM are two complementary Islamic organizations. As explained by KH. Umar Hamdan Karrar, FKM is the regeneration of AUMA, which is much older than FKM. Thus, both organizations are led and dwelled by two different generations of kiais and Madurese Muslim figures. AUMA is led by the elders and FKM is led by the younger generation of kiai which in the Madurese social context are called lora. This relationship between the elders and the younger kiais, represented by the presence of the AUMA and FKM, is an evidence of power relations phenomena which have, in praxis, the ability to control, lead, and secure all life aspects of Madurese including the people of Pamekasan.

Kiais, among the Javanese especially Madurese, cannot be viewed merely as religious leaders. They undoubtfully have a special position in the social structure of the people in the areas. In these traditions, the power and the authority of the kiais are not only in the religious realm but also extending into the social sphere. The power and the authority, borrowing Faridl's analysis, is created by itselfbegan with the societal belief to the figure of kiai-because of the deep and extensive knowledge that he has, that make him socially on 
the "elite" level among Indonesian Muslims especially Javanese and Madurese. ${ }^{41}$

Their recognition as elite social status enable them to have a crucial role as policymakers of the social object in three conditions: First, they have authority and power to make a decision; Second, they are the supporters of a moral system; Third, they have a higher position in the society and considered to be well-established figures. The presence of kiai, as a religious elite who has a significant role in Indonesian social structure, cannot be separated from the common understanding of the role of religion in daily life. The survey conducted by PEW Research Center (2015) ${ }^{42}$ concluded that Indonesia is in the third position as a nation whose society considers religion as socially important in life. This result affirms the understanding that the kiai in Indonesian social structure is placed in a higher position and respected by the people.

\section{A Counter-narrative on the Ideology of AUMA and FKM}

As we observed, the movement pattern and model run by AUMA and FKM generate many responses from society, both pros and cons just like the presence of Islamic Defender Front (FPI) and Islamic Defender Troops (LPI)—established by FPI. Some actors, mainly from the moderate Nahdliyin, resist these organizations. One of the resistances comes from PCNU (the branch of NU) with some of its autonomous bodies. Some NU activists in Pamekasan even produced counter-narratives to the movement, as shown in their discourse on religious knowledge posted on their official website: pcnu-pamekasan.or.id.

In their website, PCNU Pamekasan actively addresses recent issues, especially on the Islamism propagated by AUMA-FKM. They also held activities partnered with the autonomous bodies under PCNU to disseminate a moderate understanding of Islam such as the halaqqah ke-NU-an by LDKNU (NU Dawah Institution). KH. Musleh Adnan, a vice head of LDKNU, said that the event was for people's

\footnotetext{
${ }^{41}$ Miftah Faridl, "Peran Sosial Politik Kyai di Indonesia”, Jurnal Sosioteknologi, Vol. 6, No. 11 (2007), 238-243.

42 Angelina E. Theodorou, "Americans Are in the Middle of the Pack Globally When it Comes to Importance of Religion", Pew Research Center, December 23, 2015.
} 
protection from an Islamic ideology that contradicts the Islamic concept of rahmat li al-älamin in the spirit of nationality. ${ }^{43}$

The dynamic involvement between NU and the Islamism propagation by AUMA-FKM has made the organization suffer from a negative impact. Some of them were also involved in the vandalism conducted by FPI and LPI, such as sweeping, 212 mass protests, and a demonstration to the Regent of Pamekasan. The last demonstration was their demand to close the Cinema Mall City (KCM) in Pamekasan, ${ }^{44}$ without any dialogues. They used their sarcastic words and provocations in their oration. The orator, KH. Ali Salim, the vice head of AUMA and the leader of FPI in Pamekasan spoke:

"..Mun cengkal makéb Bupatinah obbher..sapanah sé éyobbhereh réyah, Cinema Mall-ah apah Bupatinab?”

[Transl: if the regent is stubborn-ignore our demandburn him! Which one should I burn, the Cinema Mall or the regent?]

"Budu'en kéyaéh Bupati jiyeh, mik ro deddih budu'en pate?"

[The regent is the son of a kiai, isn't he? Why he becomes the son of a dog?"]. ${ }^{45}$

The sarcastic-provocative hate speech is exaggerated when they utter the words in the name of amr ma'rüf naby munkar. Responding to the figures who often use provocative and dirty words, the leader of PCNU Pamekasan, KH. Taufik Hasyim, said that the Islamic organizations should address society with wisdom and hospitality, not by angry temperamental narratives that create disintegration in the umma and the government. ${ }^{46}$ Furthermore, he often emphasized on various occasions that he, as the leader of PCNU Pamekasan, hopes that NU becomes an organization, not a political party. Then, he said, NU does not deal with local elections and legislative elections. NU must address the umma with good manners and be committed to the Islamic dawah, according to Abl al-Sunnah wa al-Jamāab in a civilized way.

The delivered message of PCNU that is to uphold an Islamic teaching rahmat li al-älamin (Islam as love and peace) is explicitly their

\footnotetext{
43 "Perkuat Wawasan Keislaman LDNU Pamekasan Gelar Halaqah ke-NU-an" in https://pcnu-pamekasan.or.id/Accessed June 26, 2019.

44 "Demo Kota Cinema Mall Pamekasan" dalam https://matamaduranews.com /Accessed April 2, 2020.

45 An observation on demonstration in Pamekasan February 14, 2020.

${ }^{46}$ KH Taufik Hasyim (Ketua PCNU Pamekasan), Interview, April 2, 2020.
} 
response toward the propagation of Islamism in Pamekasan mainly by AUMA, FKM, FPI, and LPI. Ideologically, AUMA, FKM, FPI, LPI, and NU stand on the same theological principle Abl al-Sunnab wa alJamä $a$ ah. However, there is a different interpretation in understanding the concept of amr ma'rüf naby munkar in practice. Thus, it is quite common to see the sympathizers of AUMA, FKM, FPI, and LPI are coming from NU's culture. Nevertheless, these organizations have a reactionary character in their behavior, especially in dealing with the attitude toward any deviations. In some cases, they did not hesitate to use a confrontative, anarchic, sarcastic, and provocative manner.

On the other hand, NU highlights the moderate-inclusive attitude which is essentially the implementation of the adopted values of NU such as tasamub (tolerance), tawārun (justice), and tawassut (moderation). These values are therefore used to understand the doctrine of amr ma'rüf naby munkar. For many Nahdliyin, the values are also internalized as guidance of action as they also consider other religious propositions to avoid a textual interpretation that creates violence as practiced by other groups. In this issue, Shaykh 'Abd alHamīd al-Sharwanī, in his work Häshiyat al-Sharwani, is one of the religious propositions used to understand amr ma'rüf naby munkar. ${ }^{47}$ According to him, the implementation of the concept should be started with the lightest means:

"It is compulsory for those who implement amr ma'rüf naby munkar to execute it with the lightest manner to (gradually) heavier one. Thus, when wrongdoing can be dispersed with good words, we should not utter a bitter utterance. That is how it should be done onward." 48

Based on al-Sharwani's opinion above, the moral principle lies in the maturity and wisdom in its practice. Thus, when wrongdoing occurs, one should disperse it gradually, and not directly with full force. Sayyid Abdullāh b. Husain b. Tahir said:

"Those who implement amr ma'rüf naby munkar, they have to be merciful and caring for human beings. He should act upon it gradually... he should warn them (the wrongdoers) and frighten them in a loving way. When they do a lot of religious violations and do not able to stop all of them, we should speak on some

\footnotetext{
47 "Memahami Amar Maruf Nahi Munkar Secara Benar" in https://islam.nu.or.id /post/read/84166/ Accessed January 20, 2019.

48 'Abd al-Hamīd al-Sharwanī, Häshiyat al-Sharwanì 'alā Tuḅfat al-Muḅtäj, Vol. 7 (Beirut: Dār al-Kutub al-'Ilmìyah, 2003), 217.
} 
mistakes till they stopped some of them, then start speaking on some others, that is how it should be." 49

His perspective also implies that to act upon a phenomenon that contradicts Islamic teaching, the Muslims should not leave behind the mission of Islam as rabmat li al-'alamin.

The spirit of Islamism in this issue creates a contestation between AUMA-FKM and PCNU Pamekasan. Both organizations led by kiais strengthen and extend their influences to the umma or laypeople. AUMA and FKM are reactionary toward the deviant acts and try to lead the people to embrace their ideas. They disseminate their ideology through pesantren and their alumni networks. On the other hand, PCNU Pamekasan, led by kiais as well, attempt to oppose their mission. They work on religious moderation campaign among Pamekasan people and preach the dialogues means to the conflict for the sake of harmony in society.

The contestation was obvious when KH. Umar Hamdan Karrar posted a statement that insults KH. Mustofa Bisri (Gus Mus), ${ }^{50}$ a charismatic kiai who is most respected by NU followers. The statement gained criticism from many figures from Pamekasan to the national scope. Then, some figures in PCNU and ANSOR Pamekasan reported the leader of FKM Madura to the East Java Provincial Police (POLDA). ${ }^{51}$ After the mass criticism, KH. Umar Hamdan Karrar officially apologized to the public and visited Gus Mus in Rembang, Central Java. Another event showing the contestation was the resistance of political campaigns by KH. Ma'ruf Amin when came to Madura. He is one of the national NU leaders and the candidate of vice president accompanying Joko Widodo. In his visit, he wanted to attend haul (commemoration of a departed figure) and make a pilgrimage to the tomb of KH. Suhro. In his way, groups of people blocked his team and showed the poster of the other candidates Prabowo-Sandi. Responding to that, KH. Taufiq

\footnotetext{
49 Zayn b. Sumit, al-Minhāj al-Sañ (Jeddah: Dar al-Minhaj, 2006), 316-317.

50 "Sebut Arti Doa Gus Mus Hancurkan Indonesia Umar Minta Maaf" dalam https://m.suara.com/news/2019/05/31/095224/Accessed June 21, 2019.

51 "Hina Gus Mus Lewat Facebook, FB Pemilik Akun Umar Hamdan Karrar Akan Diperiksa Cyber Pold Jatim" dalam https://madura.tribunnews.com /2019/06/01/Accessed June 28, 2019.
} 
Hasyim-in a newspaper-expressed his disappointment and encouraged the Nahdliyyin not easily to be provoked. ${ }^{52}$

In that incident, PCNU Pamekasan can only express their disappointment because there was only a group of people, and there was no organizational actor involved, unlike the previous incident where the leader of FKM was the only responsible actor for the inappropriate statement. Yet, knowing the political preference of the religious elites in Pamekasan, especially the AUMA'a political orientation, we can highly suspect that the actors behind that disturbance are the followers of kiais in the AUMA and FKM. Thus, the contestation among figures and the different political preferences at that time was due to the severe polarization in society. The polarization was made possible by the role of religious issues played by a certain group for their interest. The religion, then, becomes a political weapon that is deadly and dangerous when using the judgment of "religious blasphemy supporter" to a person or a group who do not meet their ideas since the judgment will ruin one's political carrier.

It happened to Basuki Tjahaya Purnama (Ahok) in the Jakarta governor election 2014. In turn, he was imprisoned as accused of doing religious blasphemy. ${ }^{53}$ The claim is not only impacting politicians but also ordinary people. The polarization has ironically infiltrated into the people's daily lives, as occurred in the phenomenon of rejecting the burial of a deemed blasphemy supporter. A banner near the mosque said," This mosque does not perform a prayer to the supporter of religious blasphemy act in Southern Jakarta." ${ }^{54}$ In the rejection case of Ma'ruf Amin' by a group of people in Pamekasan, the political tension seemed to predominate the existing cultural practice in Pamekasan, that is the respect to the figure of kiai above other figures, including state apparatus ${ }^{55}$ - and Ma'ruf Amin' is one of the recognized kiais in the region.

\footnotetext{
52 Ketua PCNU Pamekasan Minta Warga NU Menahan Diri Terkait Persekusi Kiai Maruf' in https://www.merdeka.com/politik/Accessed May 28, 2019

53 "Perjalanan Kasus Ahok: Bermula dari Pidato hingga Akhirnya Dipenjara" in https://www.idntimes.com/news/indonesia/gregorius-pranandito/ Accessed May 28, 2019.

54 "Spanduk Tolak Salatkan Jenazah Terpasang di 3 Masjid di Karet Jaksel" in https://news.detik.com/berita/3431781/ Accessed May 28, 2019.

55 See "The Compilation or Extraction of Weber's Work in English version can be accessed on this page http://www.sociosite.net/topics/weber.php and http://ssr1.
} 
Based on the previous explanation, the contestation-between the group with Islamism agenda represented by AUMA-FKM vis-á-vis traditional-moderate Muslims-happened because of different interpretations on religious matters, especially in social practice which can be explained in three factors. First, FKM and AUMA tend to employ reactionary responses toward the deviation in society and even instigate violence as the solution, which is opposed by $\mathrm{NU}$ groups' cultural-persuasive manner. Second, the political preference of the elites. Their political determinism cannot be ignored as a crucial factor behind the contestation. NU's strategy to delegate one of their figures (Ma'ruf Amin, general head of Syuriah PBNU), as a vice president candidate, will generate a significant amount of voters especially in the grassroots level, although NU institutionally agreed to not participate in the practical politics as documented in the muktamar $1893 .^{56}$ Meanwhile, FKM and AUMA are in the opposite direction. As explained in the previous discussion, the leader of AUMA, KH. Karrar Sinhaji, is one of the Madurese figures who involved in the Ijtimak Ulama, which one of its declaration points was to support and assist the victory of Prabowo-Sandi in the presidential election. Third, the posted statement in social media by the leader of FKM, KH. Umar Karrar who insulted a most respected figure in NU, Gus Mus. It ignited NU sympathizers' anger at the local and national level that they reported the impropriate statement to the provincial police, where he was asked to apologize and visit Gus Mus.

The awareness of giving a counter-narrative like what has been done by PCNU Pamekasan is necessary to disseminate the religious moderation narratives in the grassroots, especially with the presence of an exclusive religious understanding in a certain area that does not

uchicago.edu/PRELIMS-/Theory/weber.html. In the authority theory, Weber divided the authority into three models: traditional, charismatic, and legal-rational. In this case, the authority of kiais as religious elites in Madura belongs to the first model. The placement refers to the long-existing tradition that makes up this authority model in society. However, an elite's authority can be inherited to his next generation, as the tradition among Madurese, in a son of kiai who is automatically a young kiai (lora). However, their authorities are put into two categories; that are traditional and charismatic. The charismatic category is gained through the knowledge and spiritual quality of an elite. See Jeff Haynes (ed.), Religion, Globalization, and Political Culture in the Third World, Springer (2016), 12.

56 Mohammad A.S. Hikam, Fiqh Kewarganegaraan: Intervensi Agama-Negara terhadap Masyarakat Sipil (Jakarta: PBPMII, 2001), 87. 
tolerate the different manifestation of the religious school of thoughts, religious ideologies, as well as political preferences. In short, it is necessary to disseminate the spirit of Islam as the grace giver to the whole universe. PCNU Pamekasan and other moderate Muslim groups believe that the extreme, radical, and intolerant interpretations will harm the inter-religious harmony in the society. Furthermore, it will badly impact on nationalist commitment among the majority of the Madurese. Yet, the problem in such religious interpretation issues cannot instantly be solved.

Therefore, preventive action is necessary to counter such religious understanding that does not uphold the principle of the common good in Islam (maslahat al-ämmah) by involving the wisdom by the kiais and religious figures who concern on the religious moderation.

\section{Concluding Remarks}

The power-knowledge relation constructed by the elder and the younger kiais, represented by AUMA and FKM, tend to spread intolerance among the Madurese. Their religious understanding and ummah concept imply a militancy in their ideological narratives, including Islamic survivalism, building a global caliphate. In consequence, their resistance is manifested into an extreme, radical, and intolerant movement.

Then, religious moderation can be a counter-narratives on such intolerant-exclusive ideology by AUMA-FKM-which might be applied as well to other similar exclusive groups. After the observation of the militant movement above, we figure out that the face of Islam in Madura is not wholly moderate, especially because of the presence of these organizations. The victory of Prabowo-Sandi in Madura-in 2019 the presidential election-informed us that the growing networks among FPI, AUMA, and FKM in assisting the potential voters of the candidate pairs in Madura has strengthened the inclusion of intolerant conservative Muslims as well as the Wahhabis into the interplay of politics and Islamism in Madura. Thus, it is an alert to moderate Islam to take a role in producing counter-narratives to block radical, extreme, intolerant religiosity. 


\section{References}

\section{A. Book/Journal}

A'la, Abd., Mukarrom, Ahwan., Zamzami, Mukhammad. "Islam dan Agamaisasi Politik: Studi Analisis Terhadap Peran dan Pergerakan Forum Kiai Muda (FKM) Pamekasan Madura", Jurnal Review Politik, Vol. 8, No. 1, 2018.

-----. "Kontribusi Aliansi Ulama Madura (AUMA) dalam Merespons Isu Keislaman dan Keumatan di Pamekasan Madura", Religió: Jurnal Studi Agama-agama, Vol. 8, No. 2, 2018.

A'la, Abd., Zamzami, Mukhammad., Udin, Nur Hidayat Wakhid., Aniq, Ahmad Fathan. "Islamism in Madura: From Religious Symbolism to Authoritarianism", Journal of Indonesian Islam, Vol. 12, No. 2, 2018.

Anggaran Dasar Forum Kiyai Muda Madura, published by FKM Madura.

Bruinessen, Martin van. NU: Tradisi, Relasi-relasi Kuasa, Pencarian Wacana Baru. Yogyakarta: LKiS, 1994.

Chalik, Abdul. "Elite Lokal Berbasis Pesantren dalam Kontestasi Pemilihan Kepala Daerah di Jawa Timur", KARSA: Jurnal Sosial dan Budaya Keislaman, Vol. 23 No. 2, December 2015.

Chalik, Abdul. "Religion and Local Politics: Exploring the Subcultures and the Political Participation of East Java NU Elites in the Post-New Order Era", Journal of Indonesian Islam, Vol. 4, No. 1, 2010.

Dhofier, Zamakhsari. Tradisi Pesantren: Studi tentang Pandangan Hidup Kyai. Jakarta: LP3ES, 1982.

Dovidio, J.F. M., Hewstone, Glick, P., and Esses, V.M. "Prejudice, Stereotyping and Discrimination: Theoretical and Empirical Overview", in The Sage Handbook of Prejudice, Stereotyping and Discrimination. California: Sage Publication, 2010.

Faridl, Miftah. "Peran Sosial Politik Kyai di Indonesia", Jurnal Sosioteknologi, Vol. 6, No. 11, 2007.

Foucault, Michel. Selected Interview and Other Writings 1972-1977. Brighton: The Harvester Press, 1980.

Haynes, Jeff (ed.). Religion, Globalization, and Political Culture in the Third World, Springer, 2016.

Hikam, Mohammad A.S. Figh Kewarganegaraan: Intervensi Agama-Negara terbadap Masyarakat Sipil. Jakarta: PBPMII, 2001. 
Horikoshi, Hiroko. Kyai dan Perubahan Sosial, Trans. Umar Basil and Andi Muwarly. Jakarta: P3M, 1987.

Karim, Abdul Gaffar. 'Pesantren' in Power: Religious Institutions and Political Recruitment in Sumenep, Madura", RIMA: Review of Indonesian and Malaysian Affairs, Vol. 42, No. 1, 2008.

Madjid, Nurcholish. Bilik-bilike Pesantren: Sebuah Potret Perjalanan. Jakarta: Paramadina, 1997.

Mansurnoor, Iik Arifin. Islam in an Indonesian World: Ulama of Madura. Yogyakarta: Gadjah Mada University Press, 1990.

Moesa, Ali Maschan. Kyai dan Politik dalam Wacana Civil Society. Surabaya: Lepkiss, 1999.

Pribadi, Yanwar. "Religious Networks in Madura: Pesantren, Nahdlatul Ulama, and Kiai as the Core of Santri Culture", al-Jami'ab: Journal of Islamic Studies, Vol. 51, No. 1, 2013.

Sumit, Zayn bin. al-Minhäj al-Sawì. Jeddah: Dar al-Minhaj, 2006.

Sharwanī (al), 'Abd al-Hamīd. Hāshiyat al-Sharwanì 'alā Tuhfat al-Muḅtāj, Vol. 7. Beirut: Dār al-Kutub al-'Ilmìyah, 2003.

The fatwa of MUI East Java Province no. Kep-01/SKFMUI/JTM/I/2012.

Theodorou, Angelina E. "Americans Are in the Middle of the Pack

Globally When it Comes to Importance of Religion", Pew Research Center, 23 December 2015.

\section{B. Interview and Observation}

KH. Ali Karrar Shinhaji (the leader of AUMA), Interview, Pamekasan June 22, 2017.

KH. Imadul Haq Fadholi (Secretary General of FKM), Interview, Pamekasan July 14, 2017.

KH. Nawawi Toha (the leader of AUMA Pamekasan), Interview, Pamekasan, August 6, 2018.

Ahnu Idris (the leader of Ormas Gerakan Santri and Pelajar Rahmatan Lil'alamin (GESPER), Interview, Pamekasan August 17, 2016.

An observation on demonstration in Pamekasan February 14, 2020.

KH Taufik Hasyim (Ketua PCNU Pamekasan), Interview, April 2, 2020.

KH Ali Karrar Shinhaji (Ketua AUMA), Interview, Pamekasan June 22, 2017. 
KH. Umar Hamdan Karrar (Ketua FKM), Interview, Pamekasan, July 30, 2018.

\section{Internet}

"Aktivis Muda NU Sayangkan Sikap Politik Kiai Madura" dalam santrinews.com/Nasional/1532/Accessed on January 13, 2018.

"Aliansi Ulama Madura Dukung Ustad Abdul Somad Jadi Wapres Prabowo" in suaraindonesia.co.id/read/1011/20180809/174 828/Accessed January 20, 2019.

"Demo Kota Cinema Mall Pamekasan" dalam https:// matamaduranews.com/Accessed April 2, 2020.

"Didukung Kiai se-Madura Prabowo Yakin Menang Pilpres" in www.liputan6.com/indonesia-baru/read/ 2068108/Accessed on June 29, 2017.

"Habib Zein Al-Kaff: Kalau Wahabi Masih Ahlussunnah, Sedangkan Syiah Bukan" in nahimunkar.org/Accessed in June 26, 2017.

"Hina Gus Mus Lewat Facebook, FB Pemilik Akun Umar Hamdan Karrar Akan Diperiksa Cyber Pold Jatim" dalam https:// madura.tribunnews.com /2019/06/01/Accessed June 28, 2019.

"Kapolda Jatim Sambut Kunjungan Ketua Aliansi Ulama Madura" in https://tribratanewspoldajatim.com/berita/MTA2NTc=/Acce ssed on May 20, 2019.

"Ketua PCNU Pamekasan Minta Warga NU Menahan Diri Terkait Persekusi Kiai Maruf' in https://www.merdeka.com/politik /Accessed May 28, 2019

"Kiai Madura Sebut Tak Main-main Mendukung Prabowo-Sandi" dalam jurnalmojo.com/2019/01/20.

"Kiai Pesantren di Madura Keluarkan Tausiah Dukung PrabowoHatta", in regional.kompas.com/read/2014/06/24/2010301 /Accessed on January 27, 2017.

"Memahami Amar Maruf Nahi Munkar Secara Benar" in https://islam.nu.or.id / post/read/84166/ Accessed January 20, 2019.

"Perjalanan Kasus Ahok: Bermula dari Pidato hingga Akhirnya Dipenjara" in https://www.idntimes.com/news/indonesia /gregorius-pranandito/ Accessed May 28, 2019.

"Perkuat Wawasan Keislaman LDNU Pamekasan Gelar Halaqah keNU-an” in https://pcnu-pamekasan.or.id/Accessed June 26, 2019. 
"PKS dan FPI Siap Menangkan Prabowo-Sandi di Madura" in news.okezone.com/read/2019/02/27/ 605/2023531/Accessed January 20, 2020.

"Ribuan Warga Pamekasan Madura Deklarasi Kemenangan PrabowoSandi, Masih Kukuh Sebut Menang 62 Persen", in suryamalang.tribunnews.com/2019/05/12/ accessed on Januari 3, 2020.

"Ribuan Warga Pamekasan Madura Deklarasi Kemenangan PrabowoSandi, Masih Kukuh Sebut Menang 62 Persen" in surya malang.tribunnews.com/2019/05/12/Accessed on July 20, 2019.

"Sebut Arti Doa Gus Mus Hancurkan Indonesia Umar Minta Maaf" dalam https://m.suara.com/news/2019/05/31/095224/ Accessed June 21, 2019.

"Spanduk Tolak Salatkan Jenazah Terpasang di 3 Masjid di Karet Jaksel" in https://news.detik.com/berita/3431781/ Accessed May 28, 2019.

"Ulama Madura Tabayun ke Menag Soal LGBT", in republika.co.id/berita/dunia-islam/islam-nusantara/18/01/11/ Accessed July 20, 2019. 